\title{
MARKETING CHANNEL OF THE TILAPIA IN HARAU SUB DISTRICT
}

\author{
Regia Indah Kemala Sari \\ Politeknik Pertanian Negeri Payakumbuh \\ Email: regia_sari@yahoo.co.id
}

\begin{abstract}
This study aims to analyze the flow of tilapia trade in Harau Regency and the function of the trading system carried out in marketing tilapia in Harau Regency. The research was conducted in Nagari Solok Bio-Bio, Harau District, Lima Puluh Kota Regency. The research sample was tilapia cultivation farmers selected by random sampling and tilapia marketing institutions in Nagari Solok Bio Bio, Harau Regency, namely traders and retailers using the snowball sampling method. The results showed that there were three patterns of tilapia marketing channels in Harau District, namely Channel 0: Farmers/pokdakan $\rightarrow$ Final consumers; Channel II: Farmers/pokdakan $\rightarrow$ Retailers $\rightarrow$ Final consumers; Channel III : Farmers/pokdakan $\rightarrow$ wholesalers $\rightarrow$ Retailer Traders $\rightarrow$ Final Consumers. The trading functions carried out include the functions of selling, buying, grading, transporting, storing and facilitating.Keywords : tata niga, saluran pemasaran, ikan nila.
\end{abstract}

\section{Keywords: Marketing Channel, Tilapia, Harau Sub district}

\section{INTRODUCTION}

Lima Puluh Kota Regency is one of the centers of freshwater fish farming in West Sumatra. Lima Puluh Kota Regency has fishery resource potential of 18,954.17 Ha, consisting of aquaculture with an area of 15,164.92 $\mathrm{Ha}$ and public waters (rivers, reservoirs, and other inundations) covering an area of 3,789.25 Ha. Based on this potential, $1692.09 \mathrm{Ha}(11.16 \%)$ have been utilized for aquaculture and an area of $574.68 \mathrm{Ha}(15.16 \%)$ has been utilized for inland public waters (Lima Puluh Kota Regency of Fisheries offices, 2019).

Tilapia is one of the potential freshwater fisheries for public consumption. Based on data from Statistic Indonesia of Lima Puluh Kota Regency (2019), it is known that the production of tilapia (cultivated) in Harau sub District is the highest production compared to other sub-districts in Lima Puluh Kota Regency. In Harau sub District, tilapia production in 2018 was 2,530.69 tons, in Guguak District it was 1,347.16 tons, and 1,181.84 tons for Luak District.

Fishery business is an agribusiness system that is interrelated with each other. The marketing factor for fish products is a complex process because it is generally carried out on a small scale, scattered locations, longer channels and more intermediary traders are involved (Suparmin, et al, 2013). The length of the trade system and the many institutions involved in the trade system will cause a price difference (trading margin) between the price received by producer farmers and the price received by consumers. The difference between the price received by producer farmers and the price received by the final consumer formed will affect the farmer's share.

The distance between producer farmers and consumers will determine the length of the distribution channel of the trade system. The farther the distance allows the emergence of various risks that must be borne and will affect the costs of the trading system that must be borne by the marketing agency. Improvements in the trade system are expected to increase the value received by producer farmers, reduce trade system costs and create selling prices within the limits of consumers' purchasing power (Husinsyah, 2005). Therefore, to find out the length and shortness of the tilapia trade system in Harau District, a research on the performance of the tilapia trade system and marketing institutions involved in the tilapia trade system was carried out in Harau District. The purpose of this study was to analyze the performance of the tilapia trading channel in Harau District and to find out the functions of the trade system carried out in marketing tilapia in Harau District.

\section{RESEARCH METHOD}


The research was conducted in Nagari Solok Bio-Bio, Harau District, Lima Puluh Kota Regency. Based on data from the BPS Regency of Lima Puluh Kota, it is known that Nagari Solok Bio Bio is the center for Tilapia production in Harau District. The research sample is tilapia farmers/producers and marketing agency actors. The sample for breeders/producers was 19 farmers/producers of tilapia who were selected using a random sampling technique, namely the selection of sample members was carried out by simple random sampling of tilapia farmers/producers in Harau District. The actors of marketing institutions are seen based on the existing trading channels in Nagari Solok Bio Bio, namely 1 collector and 38 retailers. Collecting data on collectors to retailers using the snowball sampling method.

Primary data taken from breeders/producers includes respondent profiles, business profiles, types and amounts of tilapia cultivation costs. Primary data taken from collecting traders or agents include fish species, purchase price at producer farm level, size, quantity, destination market, distribution mechanism, marketing costs, selling price to retailers. Primary data taken from retailers include the type of fish, purchase price, size, quantity, marketing costs, selling price to the final consumer. Secondary data in this study were obtained from the BPS Regency of Lima Puluh Kota and research journals related to the research topic.

To analyze the channels of trade and the duties and functions of the tilapia marketing agency in Harau District, it was carried out using a descriptive method. The functions of the trade system carried out in marketing tilapia can be seen in Table 1 .

Table 1. The function of marketing channel

\begin{tabular}{lllll}
\hline Function of marketing channel & \multicolumn{3}{c}{ marketing channel } \\
\cline { 2 - 4 } & & farmer & wholesalers & retailer \\
\hline$>$ Exchange & $\sqrt{ }$ & $\sqrt{ }$ & $\sqrt{ }$ \\
$>$ Pales & & & \\
$>$ Physical & & $\sqrt{ }$ & \\
$>$ Storage & $\sqrt{ }$ & & \\
$>$ Transportation & & & $\sqrt{ }$ \\
$>$ Processing & & $\sqrt{ }$ & \\
$>$ Facilities & & & \\
$>$ Standardization & $\sqrt{ }$ & & \\
$>$ Risk & & & \\
$>$ Financing & & & & \\
\hline
\end{tabular}

\section{RESULTS AND DISCUSSION}

\section{Characteristics of Tilapia Farmers and Marketing Channel in Solok Bio Bio Village}

Solok Bio-bio Village is located in Harau sub District, Lima Puluh Kota Regency, West Sumatra Province. The area of Solok Bio-bio village is $28.4 \mathrm{~km}^{2}$ or 6.80 percent of the total area of Harau sub District. In 2018 Solok Bio-Bio village was recorded to have a population of 2,056 people, consisting of 1,013 men and 1,043 women. This village is about $6 \mathrm{~km}$ from the sub-district capital, 4 kilometers from the capital city of Sarilamak Regency. Solok Bio-bio village is located in an area with a land elevation of $523 \mathrm{M}$ above sea level, with a topography consisting of high land and low or wavy land. The Solok Bio-Bio village is bordered on the north by Harau village, on the south by Gurun village, on the west by Simpang Kapuak village and on the east by Tarantang village. This village has an area of 2,263 Ha consisting of 4 (four) "jorong" which can be seen in Table 2.

Table 2. Jorong name and its size in Solok Bio-Bio Village, Harau sub District

\begin{tabular}{|c|c|c|}
\hline No. & Jorong Name & Area $(\mathrm{Ha})$ \\
\hline 1. & Solok dalam & 763 \\
\hline 2. & Padang laweh & 674 \\
\hline 3. & Bio-Bio & 656 \\
\hline 4. & Sungai Rumbai & 170 \\
\hline 5. & Jumlah & 2263 \\
\hline
\end{tabular}


Based on the research results, it is known that in Solok Bio Bio village there are 19 tilapia farmers. In general, the characteristics of Tilapia farmers in Solok Bio Bio village can be distinguished based on age, education level, number of household members, and business experience. Characteristics of respondents obtained from interviews using a questionnaire. The percentage characteristics of Tilapia farmers in Solok Bio Bio village can be seen in Table 3.

Table 3. Characteristics of Tilapia Farmers in Solok Bio Bio Village

\begin{tabular}{cccccc}
\hline No. & Characteristics & $\begin{array}{c}\text { total } \\
(\%)\end{array}$ & No. & Characteristics & $\begin{array}{c}\text { total } \\
(\%)\end{array}$ \\
\hline 1. & Age (years) & & 2 & Tingkat pendidikan & \\
& & 5 & & SD & 16 \\
& $\leq 25$ & 16 & & SMP & 37 \\
& $\geq 36-\leq 45$ & 21 & & SMA & 26 \\
& $>45$ & 58 & & PT & 21 \\
\hline $3 . \quad$ Number of household Members & & 4 & Business Experience (years) & 37 \\
& $<3$ & 21 & & $<5$ & 16 \\
& $3-5$ & 63 & & $5-10$ & 47 \\
\hline
\end{tabular}

Furthermore, based on the results of interviews, it is known that the average number of ponds owned by tilapia farmers in Solok Bio Bio village is 5 ponds with their own pond ownership status. The average number of seeds stocked by tilapia farmers was 16,368 fish per production with an average harvest (6 months) of 5,591 fish. Most (66.7\%) of tilapia seeds were obtained by farmers from Solok Bio Bio village itself, the rest (14.3\%) of tilapia seedlings were obtained from the Maninjau area and a small portion (4.8\%) of tilapia seedlings was obtained from Tarantang village.

Based on the characteristics of the breeders, it can be concluded that the majority of tilapia farmers in Solok Bio Bio village are adult breeders aged 45 years and over, namely $58 \%$ and a small proportion of tilapia farmers are young people aged 25 years and under, namely $5 \%$. The education level of the majority of tilapia farmers $(37 \%)$ is junior high school and farmers with elementary school education are still found as much as $16 \%$. The majority of tilapia breeders in Solok Bio Bio village have business experience of $47 \%$ more than 10 years and $16 \%$ of tilapia farmers have experience in tilapia farming with a range of 5-10 years. The number of household members of tilapia farmers is the majority (63\%) $3-5$ people and as much as $15 \%$ of tilapia farmers who have large household members of 5 people.

As for the characteristics of tilapia traders in Solok Bio Bio village, which is seen from the age, number of household members, education level and business experience, it shows that the majority of tilapia traders are in the age range of 36-45 years with the average level of education being junior high school who has had experience trying more than 10 years. For more details, see Table 4.

Table 4. Characteristics of Tilapia Marketing Channel in Solok Bio Bio village

\begin{tabular}{|c|c|c|c|c|c|}
\hline No. & Characteristics & $\begin{array}{r}\text { total } \\
(\%)\end{array}$ & No. & Characteristics & $\begin{array}{l}\text { total } \\
(\%)\end{array}$ \\
\hline \multirow[t]{5}{*}{1.} & Age (years) & & 2 & Tingkat pendidikan & \\
\hline & $\leq 25$ & - & & SD & - \\
\hline & $\geq 25-\leq 35$ & - & & SMP & 71,4 \\
\hline & $\geq 36-\leq 45$ & 71 & & SMA & 14,3 \\
\hline & $>45$ & 29 & & PT & 14,3 \\
\hline \multirow[t]{4}{*}{3.} & Number of household Members & & 4 & Business Experience (years) & \\
\hline & $<3$ & - & & $<5$ & 14,3 \\
\hline & $3-5$ & 71 & & $5-10$ & 14,3 \\
\hline & $>5$ & 29 & & $>10$ & 71,4 \\
\hline
\end{tabular}




\section{Tilapia Marketing Channels in Harau District}

Marketing channels can be formed by the association of several marketing institutions. Based on the results of the research that has been carried out, it can be described about the pattern of tilapia marketing channels in Solok Bio-Bio village, Harau sub District. Collecting data to find out the various marketing results of tilapia used, obtained by tracing the marketing channels of tilapia from farmers to consumers. The following is a picture of the types of marketing channels 0 , I, and II used by tilapia farmers in Solok Bio-Bio village, Harau sub District:

1. Channel $0:$ Farmer $\rightarrow$ Consumer

2. Channel I : Farmers $\rightarrow$ Retailers $\rightarrow$ Consumers

2. Farmers $\rightarrow$ Collectors $\rightarrow$ Retailers $\rightarrow$ Consumers

If depicted in a single unit, the marketing channels used by tilapia farmers in Solok Bio-Bio village, Harau sub District, can be seen in Figure 1.

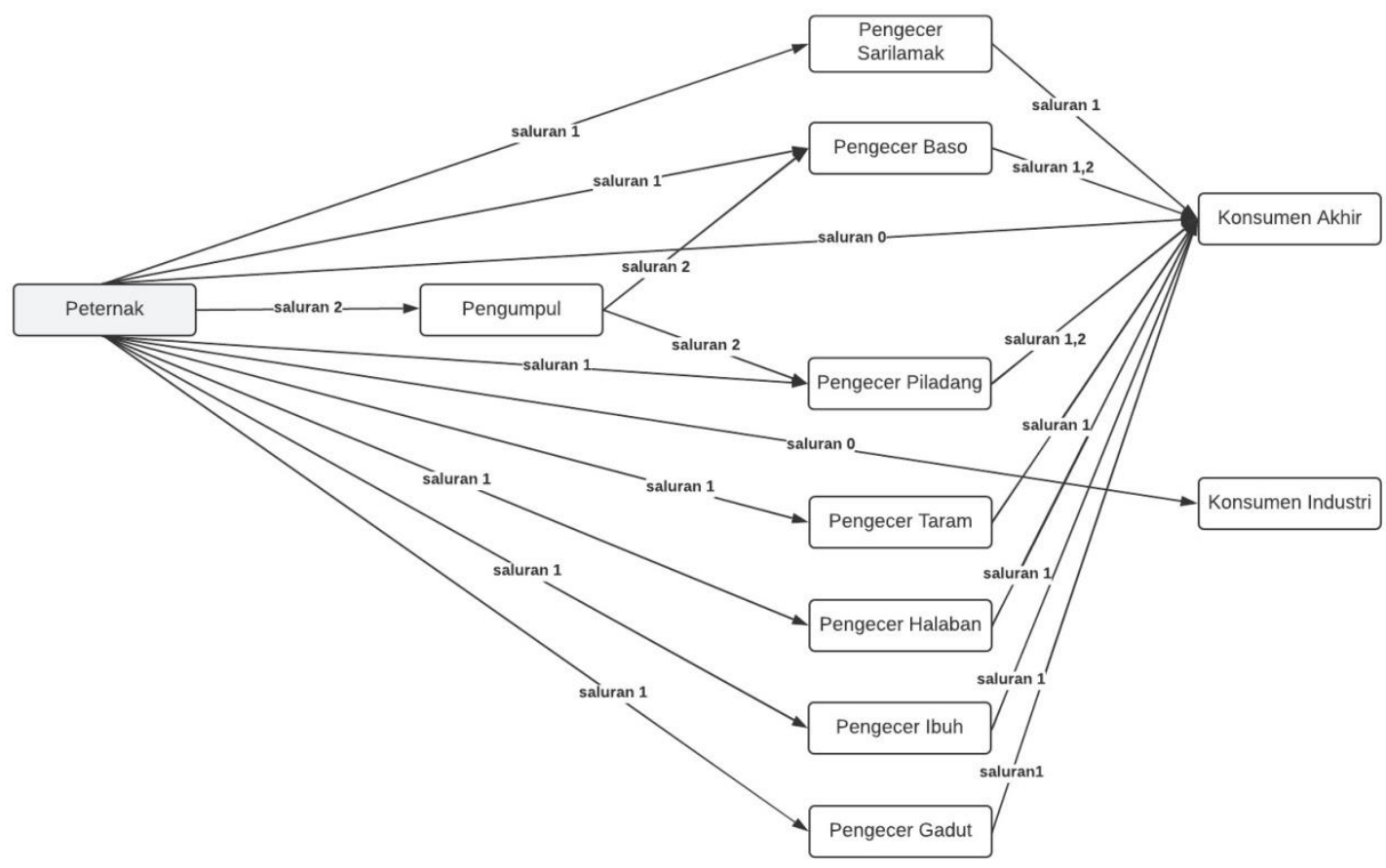

Figure 1. Pattern of Tilapia Marketing Channel in Solok Bio-Bio village, Harau sub District

Based on the tilapia marketing channel chart in Solok Bio Bio village, Harau sub District, the marketing of tilapia is through three channels, namely:

1. Marketing Channel 0

In marketing channel 0 , farmers sell red tilapia to final consumers. Tilapia marketing in this channel is to meet household consumption. In this channel, farmers directly offer tilapia to final consumers in traditional markets. The average selling price of tilapia in this channel is Rp. $25,000 / \mathrm{kg}$.

2. Marketing Channel I

In marketing channel I, farmers sell tilapia to retailers. Sales are carried out by means of retailers visiting the farmers at their homes. Then retailers sell tilapia to consumers by selling their wares in traditional markets. These retailers are spread across various regions such as Sarilamak, Piladang, Taram, Halaban, Ibuh, Gadut and Baso. In channel I the marketing of tilapia also aims to meet the demand for tilapia inside and outside the Regency of Fifty Cities. 


\section{Marketing Channel II}

In the second marketing channel pattern, farmers sell tilapia to collectors. Sales are carried out by means of traders visiting the farmers at their homes. The consumers of these wholesalers are consumers outside the Fifty Cities Regency, namely Baso and within the Fifty Cities Regency, namely Piladang.

\section{Tilapia Marketing Institutions and Functions in Harau Sub District}

Marketing institutions include individuals or groups who are directly involved in the marketing process of tilapia in Solok Bio Bio village. According to Sudiyono (2002), a marketing agency is a business entity or individual that organizes marketing, distributes services and commodities from producers to final consumers. And have relationships with other business entities or individuals. The task of the marketing agency is to carry out the marketing function and fulfill consumer needs. According to Rahardi et al (1986), the role of marketing institutions is as follows:

a. Entrepreneur/producer

Is a person who invests capital directly or indirectly related to production. The role of the producer participates in determining the success and quality of a product.

b. b. Collector traders

A trader who collects fishery commodities from entrepreneurs, fish farmers, or fishermen in large enough quantities to be re-marketed to other traders.

c. Wholesalers

A trader who buys fishery commodities from collectors or directly from producers/entrepreneurs for resale. The commodity is resold to industry, restaurants, commercial consumers, and others who do not resell in equal quantities to the final consumer.

d. Retailer

Is a trader who sells fishery commodities directly into the hands of consumers with the aim of meeting consumer needs in small parties.

Based on the results of the study, the duties and functions of marketing institutions in Nagari Solok Bio-Bio, Harau District can be seen in Table 5.

Table 5. Duties and Functions of Tilapia Marketing channel in Solok Bio-Bio village Harau sub District

\begin{tabular}{clll}
\hline No & \multicolumn{1}{c}{ Marketing Channel } & \multicolumn{1}{c}{ Tugas dan Fungsi Lembaga Pemasaran } \\
\hline 1 & Farmer & - & Perform sales function \\
2 & wholesalers & Doing grading on tilapia & Perform buying and selling functions \\
& & - $\begin{array}{l}\text { Performing the function of transportation and temporary storage } \\
\text { Performing a smoothing function which includes underwriting } \\
\text { the risk of damage and conveying information to parties in need } \\
\text { (consumers) }\end{array}$ \\
& - $\begin{array}{l}\text { Perform buying and selling functions } \\
\text { Retailers }\end{array}$ & $\begin{array}{l}\text { Performing the function of transportation and temporary storage } \\
\text { Performing the smoothing function which includes underwriting } \\
\text { the risk of damage and conveying information to parties in need } \\
\text { (consumers) }\end{array}$ \\
& &
\end{tabular}

Based on the results of the study, the duties and functions of the marketing agencies in Nagari Solok Bio-Bio, Harau District are as follows:

a. Producer/breeder.

Tilapia farmers are people who cultivate fish from seed until it is ready for consumption. Tilapia farmers in Nagari Solok Bio Bio perform the function of selling to consumers (traders). To produce good quality tilapia, it cannot be separated from maintenance and regular feeding. Feeding is done twice a day in the morning and evening to stimulate fish 
growth. Tilapia is ready to be harvested after 6 months or depending on the size of the seed used by the breeder. The size of the seed used by tilapia farmers in Nagari Solok Bio Bio is 1 inch or $3 \mathrm{~cm}$. The larger the size of the seeds used, the farmers will harvest quickly and vice versa if the size of the seeds is getting smaller, the time for harvesting will also be longer. The average price of tilapia seeds purchased by farmers is Rp. 84,- per head. The area of origin of the majority of the breeders obtained from Nagari Solok Bio Bio (66.7\%); Maninjau (14.3\%); Tarantang, BBI Koto Nan Empat, Batu Sangkar and Andalas $(4.8 \%)$. Farmers in selling tilapia on average in $1 \mathrm{~kg}$ containing 4-6 tails or according to consumer demand.

b. Collector's Field.

Collecting traders in carrying out their duties perform several functions, namely the function of grading, buying and selling, the function of transportation and temporary storage and the function of smoothing. Before the tilapia is harvested, the collectors perform grading of the tilapia. Grading is done to get a uniform size of fish that is adjusted to consumer demand. The purchase function is carried out by collectors when buying tilapia from farmers. Collecting traders buy red tilapia from farmers, usually $1 \mathrm{~kg}$ containing between 4-6 tails. The sales function is carried out by collectors when selling tilapia to retailers in traditional markets (Baso and Piladang markets). In addition to buying and selling activities, traders also carry out transportation/transportation activities to deliver tilapia to retailers in the Baso and Piladang areas. The payment system made by collecting traders to farmers is cash. Collecting traders also perform a smoothing function which includes underwriting the risk of damage, and conveying information to those in need. The function of underwriting the risk of damage is if the tilapia is not sold out so that the collecting traders will experience losses. However, because the collecting traders have subscribed to the retailers who usually buy their merchandise, the risk of loss can be avoided because the merchandise is always sold out. In addition, collectors have the function of conveying information to consumers (retailers) regarding the development of tilapia prices. So that retailers know the development of prices both at the farmer level and at the level of collectors.

c. Retailer

Retailers in carrying out their duties perform several functions, namely the function of buying and selling. The purchase function is carried out by retailers when buying tilapia to collectors and farmers, while the sales function is carried out by retailers when selling tilapia to consumers. The consumers of this diluent trader are household consumers. Household consumers who buy tilapia from retailers to meet their own consumption needs. The payment system used by retailers is cash by way of being paid directly at the time of the transaction. Retailers in carrying out their duties carry out several activities, namely packaging, transportation, temporary storage. Temporary storage is done by using ice cubes so that the tilapia is kept fresh.

\section{CONCLUSION}

There are three patterns of tilapia marketing channels, namely Channel 0: Farmers/pokdakan $\rightarrow$ Final consumers; Channel II: Farmers/pokdakan $\rightarrow$ Retailers $\rightarrow$ Final consumers; Channel III : Farmers/pokdakan $\rightarrow$ Collector Traders $\rightarrow$ Retailer Traders $\rightarrow$ Final Consumers. The trading functions carried out include the functions of selling, purchasing, grading, transporting, storing and facilitating. 


\section{REFERENCES}

Asmarantaka R. 2012. Pemasaran Agribisnis (Agrimarketing). Rosiana N. Departemen Agribisnis FEM-IPB. Bogor.

BPS Kabupaten Lima Puluh Kota. 2019. Kabupaten Lima Puluh Kota dalam Angka 2019. https://limapuluhkotakab.bps.go.id/publication/2019/08/16/810380786eee334d452bb210/kab upaten-lima-puluh-kota-dalam-angka-2019.html. Tanggal akses 18 Februari2020.

Husinsyah. 2005. Sistem Tataniaga Pisang Kepok untuk Meningkatkan Ekonomi Masyarakat Tani di Propinsi Kalimantan Timur. EPP.Vol.2.No.1.2005:1-10. Jurnal Ekonomi Pertanian dan Pembangunan. Universitas Mulawarman. Samarinda.

Kohls R L and J.N.Uhl. 2002. Marketing of Agriculutural Products. A Prentice_Hall Upper Saddle River. New Jersey.

Limbong W.H, Sitorus P. 1987. Pengantar Tataniaga Pertanian. Fakultas Pertanian. Institut Pertanian Bogor. Bogor.

Suparmin, Novira Kusrini dan Eva Dolorosa. 2013. Analisis Distribusi Pemasaran Ikan Air Tawar Hasil Usaha Budidaya Keramba Jaring Apung (KJA) di Kota Pontianak. Jurnal Eksos. Juli 2013. Vol 9. No.2. Politeknik Negeri Pontianak.

Usman, Yusri. 2013. Modul Pemasaran Hasil Pertanian. Padang. Fakultas Pertanian. Universitas Andalas. 100 hal. (Bahan Ajar). 
Volume 1 No 2 (2021)

Marketing Channel Of The Tilapia In Harau Sub District

DOI: $10.54443 /$ ijebas.v1i2.94 